2003

\title{
Between Sanctity and Depravity: Law and Human Nature in Martin Luther's Two Kingdoms
}

Witte Jr.

Follow this and additional works at: https://digitalcommons.law.villanova.edu/vlr

Part of the Legal History Commons, and the Religion Law Commons

\section{Recommended Citation}

Witte Jr., Between Sanctity and Depravity: Law and Human Nature in Martin Luther's Two Kingdoms, 48 Vill. L. Rev. 727 (2003).

Available at: https://digitalcommons.law.villanova.edu/vlr/vol48/iss3/1

This Lecture is brought to you for free and open access by Villanova University Charles Widger School of Law Digital Repository. It has been accepted for inclusion in Villanova Law Review by an authorized editor of Villanova University Charles Widger School of Law Digital Repository. 


\title{
VILLANOVA LAW REVIEW
}

VOLUME 48

2003

Number 3

\section{Twenty-Sixth Annual Donald A. Giannella Memorial Lecture}

\section{BETWEEN SANCTITY AND DEPRAVITY: LAW AND HUMAN NATURE IN MARTIN LUTHER'S TWO KINGDOMS}

\author{
JOHN WITTE, JR.*
}

\section{INTRODUCTION}

"The better the society, the less law there will be. In Heaven there will be no law, and the lion will lie down with the lamb. . . In Hell there will be nothing but law, and due process will be meticulously observed."

Q O wrote Grant Gilmore to conclude his Storrs Lectures of 1974 on the Ages of American Law. Gilmore crafted this catchy couplet to capture the pessimistic American view of law and human nature made popular a century before by Oliver Wendell Holmes, Jr. (1841-1935). ${ }^{2}$ Contrary to the conventional portrait of Holmes as the sage and sartorial "Yankee from Olympus," 3 Gilmore's Holmes was a "harsh and cruel" man, chastened and charred by the savagery of the Civil War and the gluttony of the Industrial Revolution. These experiences had made Holmes "a bitter and lifelong pessimist who saw in the course of human life nothing but a continuing struggle in which the rich and powerful impose their will on the poor and the weak." 4

This bitter view of human life shaped Holmes's bleak view of human law, Gilmore insisted. Holmes regarded law as nothing but a barrier

* Jonas Robitscher Professor of Law, Director of Law and Religion Program, Director of Center for the Interdisciplinary Study of Religion, Emory University. I wish to thank Ms. Erin Englebrecht, J.D. (Emory) and M.T.S. (Emory) for her excellent research assistance. Portions of this text are drawn from JOHN WITTE, JR., Law And Protestantism: The Legal Teachings of the Lutheran Reformation (2002) and are used herein with permission.

1. Grant Gilmore, The Ages of American Law 111 (1977).

2. See id. at 48-56, 110,147 n.12.

3. Catherine Drinker Bowen, Yankee from Olympus: Justice Holmes and His FamiLy (1945).

4. GiLmore, supra note 1 , at 49 . 
against human depravity - a means to check the proverbial "bad man" against his worst instincts and to make him pay dearly if he yielded to temptation. ${ }^{5}$ There was no higher law in heaven to guide the law below. There was no path of legal virtue up which a man should go. ${ }^{6}$ For Holmes, the "path of the law" cut a horizontal line between between heaven and hell, between human sanctity and depravity. Law served to keep humanity and society from sliding into the abyss of hell. But it could do nothing to guide them in their ascent to heaven. ${ }^{8}$

A very similar view of law and human nature is often ascribed to the sixteenth-century German Protestant Reformer, Martin Luther (14831546). ${ }^{9}$ This perhaps helps to explain Holmes's widespread appeal among Protestant intellectuals of his day and ever since. Like Holmes, Luther is said to have propounded a bleak and desperate view of human naturedescribing persons as "totally depraved" creatures, "savage" and "wild beasts" bent on devouring and destroying each other. ${ }^{10}$ Also like Holmes, Luther is said to have regarded law as a thick "chain" or "harness" designed to keep savage sinners under some measure of control and to keep society in some semblance of order. ${ }^{11}$ For Luther, law was useful to coerce sinners to conform and to terrify them to repent. ${ }^{12}$ But law provided no ladder from hell to heaven, no pathway from depravity to sanctity. Salvation came only by faith in the Gospel, not by works of the law. Sanctifica-

5. See Oliver Wendell Holmes, Jr., The Path of the Law (1890), in Collected Legal Papers 167, 170 (1920).

6. See Michael. H. Hoffheimer, Justice Holmes and the Natural Law 86-87 (1992).

7. Holmes, supra note 5 , at 167.

8. With intended irony, Gilmore depicted Holmes's view of the law as the new creed of the "age of faith" in American law that ran from the Civil War to World War I. See Gilmore, supra note 1, at 41-67. The new catechism of this age of faith was the case law method of the American law school classroom. See id. at 57-60. The new confession was that America was a land ruled by laws, not by men. See id. at 41 . The new church was the common law court where the rituals of rule formalism presided over by the judge, with participation by the jury, would yield legal truth. See id. at 60-63. This so-called "age of faith" was, in fact, "law's black night," Gilmore wrote. Id. at 41. By comparison, "American law before the the Civil War" was a veritable "Garden of Eden" where "great judges decid[ed] great cases greatly, aware of the lessons of the past, but conscious of the needs of the future, striking a sensitive balance between the conflicting claims of local autonomy and national uniformity in an immense, diverse, and rapidly growing country, creating a new law for a new land." Id.

9. For a summary of recent literature, see John Witre, Jr., LAW And Protestantism: THe Legal Teachings of the Lutheran Reformation 23-30 (2002); Harold J. Berman \& John Witte, Jr., The Transformation of Western Legal Philosophy in Lutheran Germany, 62 S. CAL. L. Rev. 1573, 1576-79, 1650-51 (1989).

10. For further discussion of Luther's views on human nature, see infra notes $37,46-50$ and accompanying text.

11. For further discussion of the role of law in governing the earthly kingdom, see infra notes 35-37 and accompanying text.

12. For a discussion of the role of law in the earthly kingdom, see infra notes 35-37 and accompanying text. 
tion came only through the counsels of the Holy Spirit, not through the commandments of any law. ${ }^{13}$ Law and Gospel were wholly different dispensations in the conventional picture of Luther's views. The law was a sentence to hell, the Gospel an invitation to heaven.

Such pessimistic views of law and human nature have bred their own excesses, critics have charged. For Gilmore, Holmes's narrow legal formalism and functionalism fired the worst excesses of American laissez-faire capitalism and corporate monopolism that took the twin forces of the New Deal and the civil rights movement to stamp out. ${ }^{14}$ For Gilmore's German counterpart Ernst Troeltsch, Luther's removal of law from the patronage and protection of theology licensed the worst forms of German patriarchy and a totalitarian lust for power that took two bloody world wars to exorcise. ${ }^{15}$

A spate of recent books has provided a more nuanced, and often more charitable, portrait of Oliver Wendell Holmes's jurisprudence and anthropology. ${ }^{16}$ Martin Luther's infamy, however, continues in most legal circles and indeed well beyond. ${ }^{17}$

This Lecture offers a start to a more nuanced, if not more charitable, account of Luther's views of law and human nature. I recognize full well that, in some of his early revolutionary writings, Luther offered a bleak view of human law and a desperate view of human nature. But this was only a small and transient part of Luther's thought, whose deficiencies and dangers Luther soon realized-even if some of his later followers did not. In his later writings, Luther wove his early radical views of law and human nature into a complex and more balanced framework called the two-kingdoms theory (zwei Reichelehre). It was this framework, I shall argue, that gave Luther's theology of law and human nature, and of authority and human society, a more enduring and edifying form.

13. For a discussion of the role of the Gospel in providing righteousness and salvation, see infra notes 37,51 and accompanying text.

14. See Gilmore, supra note 1, at 64-67.

15. See 4 ERnst Troeltsch, Gesammelte Schriften 156-90 (1922-25); Ernst Troeltsch, Protestantism and Progress: A Historical Study of the Relation of Protestantism to THE Modern World 93-149 (W. Montgomery trans., 1912).

16. See generally Albert W. Alschuler, Law Without Values: The Life, Work, and Legacy of Justice Holmes (2000); Liva Baker, The Justice from BeaCon Hill: The Life and Times of Oliver Wendell Holmes (1991); Jeremy Cohen, Congress Shall Make No law: Oliver Wendell Holmes, the First Amendment, and Judicial Decision-Making (1989); The Essential Holmes: Selections from the Letters, Speeches, Judicial Opinions, and Other Writings of Oliver Wen. dell Holmes, Jr. (Richard A. Posner ed. \& intro., 1992); The Legacy of Oliver Wendell Holmes, Jr. (Robert W. Gordon ed., 1992); Louis Menand, The Metaphysical Club (2001); Sheldon M. Novick, Honorable Justice: The Life Of Oliver Wendell Holmes (1989); The Path of the Law and its Influences: The Legacy of Oliver Wendell Holmes, Jr. (Steven J. Burton ed., 2000); G. Edward White, Justice Oliner Wendell Holmes: Law and the Inner Self (1993); G. Edward White, Oliver Wendell Holmes: Sage of the Supreme Court (2000).

17. See Witte, supra note 9, at 28-29, 295-98; see also Steven E. Ozment, Protestants: The BirTh of a Revolution 71-72 (1992). 
Part II of this Lecture charts quickly the swing of the Lutheran Reformation from its early anti-legalism to its ultimate embrace of law. Part III analyzes Luther's two-kingdoms theory in detail, charting its new understanding of being, personhood, the church, knowledge and justice. Part IV analyzes the implications of this new two-kingdoms theory for law, society and politics in Luther's day. Part V analyzes the enduring influence of Luther's two-kingdoms understanding for contemporary Protestant theories of human dignity, equality and freedom. I conclude that Grant Gilmore's famous aphorism about the place of law in heaven and hell gets Luther's later legal lessons exactly backwards.

\section{The Reformation Context ${ }^{18}$}

The Protestant Reformation that Martin Luther unleashed in Germany in 1517 began as a loud call for freedom-freedom of the church from the tyranny of the pope, freedom of the laity from the hegemony of the clergy, freedom of the conscience from the strictures of canon law. "Freedom of the Christian" ${ }^{19}$ was the rallying cry of the early Lutheran Reformation. It drove theologians and jurists, clergy and laity, princes and peasants alike to denounce church authorities and legal structures with unprecedented alacrity. "One by one, the structures of the church were thrust into the glaring light of the Word of God and forced to show their true colors," Jaroslav Pelikan writes. ${ }^{20}$ Few church structures survived this scrutiny in the heady days of the 1520s. The church's canon law books were burned. Church courts were closed. Monastic institutions were confiscated. Endowed benefices were dissolved. Church lands were seized. Clerical privileges were stripped. Mendicant begging was banned. Mandatory celibacy was suspended. Indulgence trafficking was condemned. Annates to Rome were outlawed. Ties to the pope were severed. The German people were now to live by the pure light of the Bible and the simple law of the local community.

Though such attacks upon the church's law and authority built upon two centuries of reformist agitation in the West, it was especially Luther's radical theological teachings that ignited this movement in Germany. Salvation comes through faith in the Gospel, Luther taught, not through works of the law. All persons stand directly before God; they are not dependent upon clerics for divine mediation. All believers are priests to

18. This section is a summary of WITTE, supra note 9 , at 33-86, 119-98 and the detailed sources therein.

19. Martin Luther, De Libertate Christiana (1520), in 7 D. MARTIN Luthers WERKE: KRITISCHE GeSAMTAUSGABE 49-73 (1883) [hereinafter LuTHER], translated as Freedom of a Christian, in 31 Luther's Works 327-77 (Jaroslav Pelikan et al. eds. and trans., 1955-68) [hereinafter LUTHER's WORks]. On the wide influence of the tract, see Mark U. Edwards, Jr., Printing, Propaganda, and Martin Luther 39, 64, 100-101 (1981); Mark U. Edwards, Jr., The Reception of Luther's Understanding of Freedom in the Early Modern Period, 62 Luther-JaHRBuCH 104 (1995).

20. Jaroslav Pelikan, Spirit Versus Structure: Luther and the InstituTIONS OF THE CHURCH 5 (1968). 
their peers; they are not divided into a higher clergy and lower laity. All persons are called by God to serve in vocations; clerics have no monopoly on the Christian vocation. The church is a communion of saints, not a corporation of law. The consciences of its members are to be guided by the Bible, not governed by human traditions. The church is called to serve society in love, not to rule it by law. Law is the province of the magistrate, not the prerogative of the cleric. When put in such raw and radical terms, these theological doctrines of justification by faith, the priesthood of believers, the distinction of law and Gospel and others were highly volatile compounds. When sparked by Luther's pugnacious rhetoric and relentless publications, they set off a whole series of explosive reforms in the cities and territories of Germany in the 1520 s and 1530 s, led by scores of churchmen and statesmen attracted to the Reformation cause.

In these early years, Luther's attack on the church's canon law and clerical authority sometimes ripened into an attack on human law and earthly authority altogether. "Neither pope nor bishop nor any other man has the right to impose a single syllable of law upon a Christian man without his consent," Luther wrote famously in $1520 .{ }^{21}$ The Bible contains all the law that is needed for proper Christian living, both individual and corporate. To subtract from the law of the Bible is blasphemy. To add to the law of the Bible is tyranny. "[W]ise rulers, side by side with Holy Scripture, [are] law enough." 22 When jurists of the day objected that such radical biblicism was itself a recipe for blasphemy and tyranny, Luther turned on them harshly. "Jurists are bad Christians," he declared repeatedly. ${ }^{23}$ "Every jurist is an enemy of Christ." 24 When the jurists persisted in their criticisms, Luther reacted with vulgar anger: "I shit on the law of the pope and of the emperor, and on the law of the jurists as well."25

The rapid deconstruction of law, politics and society that followed upon such shrill rhetoric soon plunged Germany into an acute crisispunctuated and exacerbated by the peasants' war, the knights' uprising and an ominous scourge of droughts and plagues in the $1520 \mathrm{~s}$ and early 1530 s. On the one hand, the Lutheran reformers had drawn too sharp a contrast between spiritual freedom and disciplined orthodoxy within the church. Young Lutheran churches, clerics and congregants were treating their new liberty from the canon law as license for all manner of doctrinal and liturgical experimentation and laxness. Widespread confusion reigned over preaching, prayers, sacraments, funerals, holidays and pastoral duties. Church attendance, tithe payments and charitable offerings declined abruptly among many who took literally Luther's new teachings of free grace. Many radical egalitarian and antinomian experiments were

21. 36 Luther's Works, supra note 19 , at 70 .

22. $44 \mathrm{id}$. at 203.

23. 3 D. Martin Luthers Werke: Tischreden No. 2809b (K. Drescher ed., 1919) [hereinafter Tischreden]; 6 id. at No. 7029-30.

24. 3 id. at No. 2837, 3027.

25. 49 LUTHER, supra note 19 , at 302. 
engineered out of Luther's doctrines of the priesthood of believers and justification by faith-ultimately splintering the German Reformation movement into rival Evangelical, Anabaptist and Free Church sects.

On the other hand, the Lutheran reformers had driven too deep a wedge between the canon law of the church and the civil law of the state. Many subjects traditionally governed by the canon law of the Catholic Church remained without effective civil regulation and policy in many of the cities and territories newly converted to Lutheranism. The vast Church properties that local magistrates had confiscated lingered long and longingly in private hands. Prostitution, concubinage, gambling, drunkenness and usury reached new heights. Crime, delinquency, truancy, vagabondage and mendicancy soared. Schools, charities, hospices and other welfare institutions fell into massive disarray. Requirements for marriage, annulment, divorce and inheritance became hopelessly confused. A generation of orphans, bastards, students, spinsters and others found themselves without the support and sanctuary traditionally afforded by monasteries, cloisters and ecclesiastical guilds. The Catholic canon law had governed all these subjects, and many more, in detail for many centuries in Germany. The new Protestant civil law, where it existed at all, was too primitive to address these subjects properly.

In response, the Lutheran reformation of theology and the church quickly broadened into a reformation of law and the state as well. Deconstruction of the canon law for the sake of the Gospel gave way to reconstruction of the civil law on the strength of the Gospel. Castigation of Catholic clerics as self-serving overlords gave way to cultivation of Protestant magistrates as fathers of the community called to govern on God's behalf. Old rivalries between theologians and jurists gave way to new alliances, especially in the new Lutheran universities. In the 1530s and thereafter, Lutheran theologians began to develop and deepen their theological doctrines in sundry catechisms, confessions and systematic writings, now with much closer attention to their legal, political and social implications. Lutheran jurists joined Lutheran theologians to craft ambitious legal reforms of church, state and society on the strength of this new theology. These legal reforms were defined and defended in hundreds of monographs, pamphlets and sermons published by Lutheran writers from the 1530 s to 1560 s. They were refined and routinized in hundreds of new reformation ordinances promulgated by German cities, duchies and territories that converted to the Lutheran cause. By the time of the Peace of Augsburg (1555) - the imperial law that temporarily settled the constitutional order of Germany-the Lutheran Reformation had brought fundamental changes to theology and law, to spiritual life and temporal life, to church and state.

It was this combination of theological and legal reforms that rendered the Lutheran Reformation so resolute and resilient. The reality was that Luther needed the law and the jurists, however much he initially scorned 
them. It was one thing to deconstruct the framework of medieval Catholic law, politics and society with a sharp theological sword. It was quite another thing to reconstruct a new Lutheran framework of law, politics and society with only this theological sword in hand. Luther learned this lesson the hard way in the crisis years of the 1520 s, and it almost destroyed his movement. He quickly came to realize that law was not just a necessary evil, but an essential blessing in this earthly life that could give institutional form to his theological teachings. It was thus both natural and necessary for the Lutheran Reformation to move from theology to law. Radical theological reforms had made possible fundamental legal reforms. Fundamental legal reforms, in turn, would make possible further theological reforms. In the course of the 1530s onwards, the Lutheran Reformation became in its essence both a theological and a legal reform movement. It struck new balances between law and Gospel, rule and equity, order and faith, structure and spirit.

The centerpiece of this new integration was Luther's complex theory of the two kingdoms, which came together in the later 1520s and 1530s. In this two-kingdoms theory, Luther repeated much of his original theological message. But he wove his early more radical doctrines into a considerably more nuanced and integrated theory of being and order, of the person and society, of the church and the priesthood, of reason and knowledge, of righteousness and law.

\section{Luther's Two Kingdoms TheORY}

\section{A. The Garden of Errors}

In 1957, German historian Johannes Heckel called Luther's two-kingdoms theory a veritable "garden of errors," (Irrgarten) where the wheats and tares of interpretation had grown indiscriminately together. ${ }^{26}$ Some half a century of scholarship later, Heckel's little garden of errors has become a whole wilderness of confusion, with many thorny thickets of casuistry to ensnare the unsuspecting. ${ }^{27}$ It is tempting to find another way into Luther's contributions to law and human nature. But Luther's two-kingdoms theory was the framework on which both he and many of his followers built their enduring views of law and authority, justice and equity, society and politics. We must wander in this wilderness at least long enough to get our legal bearings.

26. Johannes Heckel, Im Irrgarten der Zwei-Reiche-Lehre (1957). The common translation of Irgarten is, of course, "labyrinth."

27. For a detailed bibliography on writings on the two kingdoms, see Berman \& Witte, supra note 9, at 1585-86 nn.21-23. For more recent writings, see generally Robert Benne, The Paradoxical Vision: A Public Theology for the TwentyFirst Century (1995); Per Frostin, Luther's Two Kingdoms Doctrine: A CritiCal Study (1994); Bernhard lohse, Luthers Theologie (1995); Andreas Pawlas, Die Lutherische Berufs-und Wirtschaftsethik: Eine Einführung (2000). 
Luther was a master of the dialectic-of holding two doctrinal opposites in tension and of exploring ingeniously the intellectual power of this tension. Many of his favorite dialectics were set out in the Bible and wellrehearsed in the Christian tradition-spirit and flesh, soul and body, faith and works, heaven and hell, grace and nature, the kingdom of God versus the kingdom of Satan, the things that are God's and the things that are Caesar's and more. ${ }^{28}$ Some of the dialectics were more uniquely Lutheran in accent-law and Gospel, sinner and saint, servant and lord, inner man and outer man, passive justice and active justice, alien righteousness and proper righteousness, civil uses and theological uses of the law, among others.

Luther developed a good number of these dialectical doctrines separately in his writings from 1515 to 1545 -at different paces, in varying levels of detail and with uneven attention to how one doctrine fit with others. He and his followers eventually jostled together several doctrines under the broad umbrella of the two-kingdoms theory. This theory came to describe five doctrines at once, which I shall discuss in detail: (1) the distinctions between the fallen realm and the redeemed realm, the City of Man and the City of God, the Reign of the Devil and the Reign of Christ; (2) the distinctions between the sinner and the saint, the flesh and the spirit, the inner man and the outer man; (3) the distinctions between the visible church and the invisible church, the church as governed by civil law and the church as governed by the Holy Spirit; (4) the distinctions between reason and faith, natural knowledge and spiritual knowledge; and (5) the distinctions between two kinds of righteousness, two kinds of justice, two uses of law.

When Luther or his followers used the two-kingdoms terminology, they often had one or two of these distinctions primarily in mind, sometimes without clearly specifying the same. Rarely did all of these distinctions come in for a fully differentiated and systematic discussion and application, especially when the jurists later invoked the two-kingdoms theory as part of their jurisprudential reflections. The matter was complicated even further because both Anabaptists and Calvinists of the day eventually adopted and adapted the language of the two kingdoms as well-each with their own confessional accents and legal applications that were sometimes in sharp tension with Luther's and other Evangelical views. ${ }^{29}$ It is thus worth spelling out Luther's understanding of the two kingdoms in some detail, and then drawing out its implications for law, society and politics.

28. See Oliver O'Donovan, The Desire of the Nations: Rediscovering the Roots of Political Theology 82ff., 193ff. (1996).

29. See Robert Friedmann, The Theolocy of Anabaptism 38-41 (1973); John Witte, Jr., Moderate Religious Liberty in the Theology of John Calvin, 31 Calvin THEOLOGICAL J. 359-403 (1996). 


\section{B. Theory of Being}

First and foremost for Luther, the two-kingdoms theory was an ontology, a theory of the two-fold nature of being or reality. In his early writings, Luther often described this in the familiar Augustinian terms that he had learned in the Augustinian monastery. ${ }^{30}$ Augustine's City of God was the perfect heavenly kingdom in the life hereafter. It was already experienced but not yet fully realized by Christians who sojourn in the City of Man, in this earthly kingdom of space and time. ${ }^{31}$ Sometimes, Luther described this distinction in the grand terms of the Bible-as the kingdom of God (Reich Gottes, regnum Dei) and the kingdom of Satan (Teufels Reich, regnum diaboli) locked in perennial battle for the souls of humankind until the second coming of Christ and the ultimate overthrow of the Devil. ${ }^{32}$ Sometimes, Luther focused on the contrast between two classes of citizens in the world-Christians who have accepted the lordship of Christ in the heavenly kingdom and non-Christians who submit only to the authorities of the earthly kingdom. ${ }^{33}$

All these were quite different renderings of a basic ontological dualism, but they often came tumbling out together in Luther's torrential prose. For example, in a famous 1523 passage, Luther wrote:

Here we must divide the children of Adam and all mankind into two parts, the first belonging to the kingdom of God (reych Gottis), the second to the kingdom of the world (reych der welt).

Those who belong to the kingdom of God are all true believers who are in Christ and under Christ, for Christ is king and lord in the kingdom of God. ... [T] hese people need no worldly law or sword. If all the world were composed of real Christians, that is, right believers, there would be no need for or benefits from prince, king, lord, sword, or law. They would serve no purpose, since Christians have in their heart the Holy Spirit, who both teaches and makes them do injustice to no one, to love everyone, and to suffer injustice and even death willingly and cheerfully at the hands of anyone....

30. See Hans-Ulrich Delius, Augustin als Quelle Luthers: Ein MaterialSAMMLUNG (1984).

31. See 45 Luther's Works, supra note 19 , at $88-92,104-08 ; 46$ id. at $242-43 ; 36$ Luther, supra note 19 , at $385 ; 45$ id. at $252 \mathrm{ff}$; 6 Tischreden, supra note 23 , at No. 7026 .

32. See 6 Tischreden, supra note 23, at No. 7026; see also 18 Luther, supra note 19, at 635 , where Luther writes: "Man's will is like an animal standing between two riders. If God is the rider, man goes and wills where God goes .... If Satan is the rider, man wills and goes where Satan goes." Id.

33. See 21 Luther's Works, supra note 19, at 109; 23 id. at 316-19; 36 Luther, supra note 19 , at 385 . In this early period, Luther believed that while God operates in both kingdoms, Christ operates only in the heavenly kingdom. See 14 LuTHer's Works, supra note 19 , at $19-27 ; 45 \mathrm{id}$. at 88 . 
All who are not Christians belong to the kingdom of the world and are under the law. There are few true believers, and still fewer who live a Christian life, who do not resist evil and indeed themselves do no evil. For this reason, God has provided for them a different government (Regiment) beyond the Christian estate (Stand) and kingdom of God. He subjected them to the sword so that, even though they would like to, they are unable to practice their wickedness, and if they do practice it they cannot do so without fear or with success and impunity ....

God has ordained two governments: the spiritual (geystliche), by which the Holy Spirit produces Christians and righteous people under Christ; and the temporal (welltiche), which restrains the non-Christian and the wicked. ${ }^{34}$

As the quotation reveals, Luther believed that the two kingdoms (Reiche) were ruled by two authorities or governments (Regimente, Stände). In his early years, Luther viewed these two authorities primarily through his favorite binocular of the law and the Gospel. ${ }^{35}$ The earthly kingdom was governed by law. The heavenly kingdom was governed by Gospel. Both the law and the Gospel were ultimately forms of God's authority and revelation. But they had to be carefully distinguished. ${ }^{36}$ The law was an authority of the Sword; it brought coercion, bondage and restraint. The Gospel was an authority of the Word; it promised love, freedom and charity. In this world of space and time, both these authorities ruled concurrently, and a Christian believer needed to submit to each and to resist their conflation.

Paul says in Timothy 1 [:9], "the law is not laid down for the righteous but for the lawless."

Why is this? It is because the righteous man of his own accord does all and more than the law demands. But the unrighteous do nothing that the law demands; therefore, they need the law to instruct, constrain, and compel them to do good .... In the same way a savage wild beast is bound with chains and ropes so that it cannot bite and tear as it would normally do, even though it would like to; whereas a tame and gentle animal needs no restraint, but is harmless despite the lack of chains and ropes....

If anyone attempted to rule the world by the Gospel and to abolish all earthly law and the sword on the plea that all are baptized and Christian, and that, according to the Gospel, there shall be among them no law or sword-or need for either-... [h]e

34. 11 LUTHER, supra note 19 , at 249-52.

35. See $40 \mathrm{id}$. at 486.

36. See 54 LutHER's Works, supra note 19, at 105-07; 1 Tischreden, supra note 23, at No. 590 . 
would be loosing the ropes and chains of the savage wild beasts and letting them bite and mangle everyone ....

For this reason one must carefully distinguish between these two governments. Both must be permitted to remain; the one to produce righteousness, the other to bring about external peace and prevent evil deeds. Neither one is sufficient in the world without the other. No one can become righteous in the sight of God by means of the temporal government, without Christ's spiritual government. Christ's government does not extend over all men; rather, Christians are always a minority in the midst of nonChristians. Now where temporal government or law alone prevails, there sheer hypocrisy is inevitable, even though the commandments be God's very own. For without the Holy Spirit in the heart no one becomes truly righteous, no matter how fine the work he does. On the other hand, where the spiritual government alone prevails over land and peoples, there wickedness is given free rein and the door is open for all manner of rascality, for the world as a whole cannot receive or comprehend it. ${ }^{37}$

As this quotation reveals, Luther in this early period, tended to conflate: (1) the theological category of law-the Old Testament dispensation of God that antedated the Gospel, with (2) the political category of lawthe positive laws promulgated by the magistrate. The law of God and the law of the magistrate were both part of the government of the earthly kingdom, and Luther at first did little to distinguish them. The dangers of this early position soon became apparent. For Luther, in this early period, also tended to conflate the image of the earthly kingdom as the evil realm of the Devil with that of the earthly kingdom as the political realm of the magistrate. This double conflation led the early Luther dangerously close to intimating that not only the law of the magistrate but also the law of God was part of the earthly kingdom of the Devil. Add Luther's repeated and bitter attacks on Mosaic law, canon law and Roman law alike, ${ }^{38}$ and it was easy to see how Luther's early theory could lead an earnest Evangelical follower straight into antinomianism-into wholesale rejection of all law in favor of the freedom of the Christian Gospel.

By the late $1520 \mathrm{~s}$, Luther thus moved to a more nuanced view of the temporal government that governed the earthly kingdom. Luther's earlier Augustinian picture of the earthly kingdom as the fallen and formless City of Man under the reign of the Devil faded into the background. To the foreground came Luther's new picture of the earthly kingdom as the natural realm, once a brilliant and perfect creation of God, but now darkened and distorted by the fall into sin. Despite the fall, however, God in his grace had allowed the earthly kingdom to continue to exist. God had also allowed the various natural laws and natural orders to continue to

37. 45 LuTHER's WORKs, supra note 19, at 89-92.

38. For detailed sources, see WITTE, supra note 9, at 53-69. 
operate. Luther referred many times to the natural laws of marriage and family, property and business born of God's primal command to Adam and Eve in Paradise: "Be fruitful and multiply, replenish the earth and subdue it, and have dominion over [it]." 39 Luther also pointed to the natural laws on the proper worship and honor of God, on coveting and homicide, on evidence and judicial procedure adumbrated in God's primal confrontation with Cain immediately after Paradise. ${ }^{40}$ For Luther, each of these natural laws, created by God, continued to govern the earthly kingdom after the fall into sin.

Not only the natural laws, but also the natural orders of creation continued to govern after the fall into sin. "God has ordained three orders or governments (hierarchias/Regimente)" to embody, elaborate and enforce natural laws in the earthly kingdom, Luther wrote in 1539: "the household, the state, and the church," or the ordo economicus, ordo politicus and ordo ecclesiasticus as he elsewhere put it. ${ }^{41}$

The first government (Regimente) is that of the home, from which the people come. The second is that of the "state" (civitas), that is, the country, the people, princes, and lords, which we call the temporal government. These [two governments] embrace everything-children, property, money, animals, and so on. The home must produce, whereas the city must guard, protect, and defend. Then follows the third, God's own home and city, that is, the church, which must obtain people from the home and protection and defense from the state. These are the three hierarchies ordained by God, ... the three high divine governments, the three divine, natural, and temporal laws of God. ${ }^{42}$

All three of these orders, governments or estates, Luther insisted, represented different dimensions of God's authority and law in the earthly kingdom. All three stood equal before God and before each other in discharging their essential natural tasks. All three were needed to resist the power of sin and the Devil in the earthly kingdom. All three deserved equally the obedience of those under their authority. All three were essential to the preservation of life and law, order and obligation in the earthly kingdom. All three not only exercised the justice and wrath of God against sin, but also anticipated the more perfect life and law of the heavenly kingdom. ${ }^{43}$ As Luther put it: "God wants the government of the earthly kingdom to be a symbol of . . . the heavenly kingdom, like a mime or a mask." 44

39. Genesis 1:28; see also 1 LuTHER's Works, supra note 19, at 71-72.

40. Genesis, 4:1-17; see 1 LUTHER's Works, supra note 19, at 259-310.

41. 39/1 LUTHER, supra note 19, at 42; see also 3 LUTHER's Works, supra note 19 , at $217 ; 37 \mathrm{id}$. at $364 ; 41 \mathrm{id}$. at 177.

42. 50 LUTHER, supra note 19 , at 509.

43. See 13 Luther's Works, supra note 19 , at 169.

44. 51 LUTHER, supra note 19, at 241. 
This "three-estate theory" (drei Ständelehre) became one of the signature doctrines of Lutheran theology and jurisprudence. ${ }^{45}$ It provided Luther with a considerably more nuanced and positive theory of earthly law and government than some of his earlier statements had allowed. His ontological picture of the world remained a basic dualism between a lower earthly kingdom and a higher heavenly kingdom. But the earthly kingdom was now much more clearly a realm of divinely-ordained authority and law, albeit perennially distorted by sin. And the earthly kingdom was naturally subdivided into three orders of domestic, political and ecclesiastical authority, each called to embrace and enforce God's law, and each empowered to prohibit and punish human sin.

\section{Theory of the Person}

The two-kingdoms theory was not only an ontology, a theory of the two-fold nature of reality. It was also an anthropology, a theory of the twofold nature of the Christian person. All persons in Christendom, Luther argued, share equally in a doubly paradoxical nature. Each Christian is at once a saint and a sinner, righteous and reprobate, saved and lost-simul iustus et peccator. ${ }^{46}$ At the same time, each Christian is at once a free lord who is subject to no one, and a dutiful servant who is subject to everyone.

Every Christian "has a two-fold nature," Luther argued in expounding his famous doctrine of simul iustus et peccator. We are at once body and soul, flesh and spirit, sinner and saint, "outer man and inner man." These "two men in the same man contradict each other" and remain perennially at war. ${ }^{47}$ On the one hand, as bodily creatures, we are born in sin and bound by sin. By our carnal natures, we are prone to lust and lasciviousness, evil and egoism, perversion and pathos of untold dimensions. ${ }^{48}$ Even the best of persons, even the titans of virtue in the Bible-Abraham, David, Peter and Paul-sin all the time. ${ }^{49}$ In and of ourselves, we are totally depraved and deserving of eternal death. On the other hand, as spiritual creatures, we are reborn in faith and freed from sin. By our spiritual natures, we are prone to love and charity, goodness and sacrifice, virtue and peacefulness. Even the worst of persons, even the reprobate thief nailed on the cross next to Christ's, can be saved from sin. In spite of ourselves, we are totally redeemed and assured of eternal life. ${ }^{50}$

It is through faith in the Word of God, Luther argued, that a person moves from sinner to saint, from bondage to freedom. This was the essence of Luther's doctrine of justification by faith alone. No human work

45. See Wilhelm Maurer, Luthers Lehre von den drei Hierarchien und ihr MITTELALTERLISCHER HiNTERGRUND (1970).

46. See 31 LuTHER's Works, supra note 19, at 344-47, 358-61.

47. Id. at 344 .

48. See id. at $344,358-61 ; 25 i d$. at 204-13.

49. See 19 id. at $47-48$.

50. See 31 id. at $344-54,368-77$. 
of any sort-even worship, contemplation, meditation, charity and other supposed meritorious conduct-can make a person just and righteous before God. For sin holds the person fast and perverts his or her every work. "One thing, and only one thing, is necessary for Christian life, righteousness, and freedom," Luther declared. "That one thing is the most holy Word of God, the Gospel of Christ." 51 To put one's faith in this Word, to accept its gracious promise of eternal salvation, is to claim one's freedom from sin and from its attendant threat of eternal damnation. And it is to join the communion of saints that begins imperfectly in this life and continues perfectly in the life to come.

A saint by faith remains a sinner by nature, Luther insisted, and the paradox of good and evil within the same person remains until death. But there is "a difference between sinners and sinners," Luther wrote. "There are some sinners who confess that they have sinned but do not long to be justified; instead, they give up hope and go on sinning so that when they die they despair and, while they live, they are enslaved to the world. There are other sinners who confess that they sin and have sinned, but they are sorry for this, hate themselves for it, long to be justified and, under groaning, constantly pray to God for righteousness. This is the people of God," the saints who are saved, despite their $\sin .^{52}$

This brought Luther to a related paradox of human nature-that each Christian is at once a lord who is subject to no one, and a priest who is servant to everyone. On the one hand, Luther argued, "every Christian is by faith so exalted above all things that, by virtue of a spiritual power, he is [a] lord." 53 As a redeemed saint, an "inner man," a Christian is utterly free in his conscience, utterly free in his innermost being. He is like the greatest king on earth, who is above and beyond the power of everyone. No earthly authority - whether pope, prince or parent—can impose "a single syllable of the law" upon him. ${ }^{54}$ No earthly authority can intrude upon the sanctuary of his conscience, can endanger his assurance and comfort of eternal life. This is "the splendid privilege," the "inestimable power and liberty" that every Christian enjoys. ${ }^{55}$

On the other hand, Luther wrote, every Christian is a priest, who freely performs good works in service of his or her neighbor and in glorification of God.56 "Christ has made it possible for us, provided we believe in him, to be not only his brethren, co-heirs, and fellow-kings, but also his fellow-priests," Luther wrote. And thus, in imitation of Christ, we freely serve our neighbors, offering instruction, charity, prayer, admonition and

51. Id. at 345 .

52. Luther: Lectures on Romans 120 (Wilhelm Pauck ed. \& trans., 1961); see also 8 LuTHER's Works, supra note 19, at 9-12; 12 id. at 328-30.

53. 31 id. at 354.

54. 31 id. at $344-46 ; 36$ id. at 70 .

55. 31 id. at 355-58.

56. See id. at $355-56 ; 36$ id. at 112-16, 138-40; 40 id. at 21-23; 39 id. at 137-224. 
sacrifice. ${ }^{57}$ We abide by the law of God so far as we are able so that others may see our good work and be similarly impelled to seek God's grace. We freely discipline and drive ourselves to do as much good as we are able, not so that we may be saved but so that others may be served. We live so far as we are able the life of the Beatitudes, the virtues of poverty, meekness, humility, mercy and peacefulness. 58 "A man does not live for himself alone," Luther wrote, "he lives only for others." 59 The precise nature of our priestly service to others depends upon our gifts and upon the vocation in which God calls us to use them. ${ }^{60}$ But we are all to serve freely and fully as God's priests.

Such are the paradoxes of human nature, Luther believed. We are at once sinners and saints; we are at once lords and servants. We can do nothing good; we can do nothing but good. We are utterly free; we are everywhere bound. The more a person thinks himself a saint, the more sinful in fact he becomes. The more a person thinks herself a sinner, the more saintly in fact she becomes. The more a person acts like a lord, the more he is called to be a servant. The more a person acts as a servant, the more in fact she has become a lord. This is the paradoxical nature of human life.

Luther's first distinction between the saint and the sinner tracked closely his ontological distinction between the City of God and the City of Man, the reign and realm of Christ versus that of the Devil. ${ }^{61}$ Sinners are earthly citizens. Saints are heavenly citizens. Every Christian is both a sinner and a saint. Every Christian is a citizen of both the earthly and the heavenly kingdoms. Earthly citizenship comes with birth. Heavenly citizenship comes through faith.

Luther's second distinction between free lord and priestly servant did not track his ontological distinctions so neatly. In one sense, this lordpriest distinction was a description only of the Christian saint, only of a member of the heavenly kingdom. Both lordship and priesthood after all were qualities of the Christian believer, the party who had been justified by faith, and had so become a citizen of the heavenly kingdom. As lord, such a heavenly citizen was utterly free from the strictures and structures of the law of the earthly kingdom. As priest, he or she was utterly free to do good works for neighbors, even if such works could never fully comply with God's law.

In another sense, however, the lord-priest distinction did track the two-kingdoms distinction. To be a lord was to be above everyone in the

57. $32 i d$. at $355 ; 36 i d$. at 241.

58. See $45 \mathrm{id}$. at 87.

59. $31 \mathrm{id}$. at $364-65$.

60. See 38 id. at 188; 28 id. at 171-72.

61. Indeed, Luther developed his anthropological dualism in detail already in his Freedom of a Christian (1520), in 31 LUTHER's WORKs, supra note 19, at 327, and he developed his ontological dualism in detail in his Temporal Authority: To What Extent it Should be Obeyed (1523), in 45 LUTHER's WORKs, supra note 19, at 75. 
earthly kingdom, to be "an inner man," to "live for oneself alone," to have the assurance and luxury of being in utter community and compatability with God, above the sinful din of the earthly crowd. To be a priest, however, was to be servant to everyone-in the heavenly and the earthly kingdoms alike. It was to be an "outer man," a "person for the sake of others"-not least those sinful non-believers of the earthly kingdom who will see in this service a reflection of and an invitation to a saintly Christian life in the heavenly kingdom. Luther's doctrine of the priesthood of all believers did not connote a priesthood to believers only. It connoted a priesthood by believers both to fellow believers in the heavenly kingdom and to non-believers in the earthly kingdom-in imitation of Christ's priestly service on earth. As Luther put it: "The fact that we are all priests and kings means that each of us Christians may go before God and intercede for the other, asking God to give him his own faith." 62 Thus a Christian believer, in discharging the services of the priesthood of believers, inevitably moved between the heavenly and the earthly kingdoms.

\section{Theory of the Church}

Luther's two-kingdoms theory also drew to itself an ecclesiology, a theory of the two-fold nature of the church. Parts of this ecclesiology we just saw foreshadowed in Luther's discussion of a Christian as a saint of the heavenly kingdom and a priest of the earthly kingdom. Other parts of this theory we saw earlier in Luther's description of the church as one of the three natural orders of the earthly kingdom. ${ }^{63}$

Luther distinguished the invisible church of the heavenly kingdom from the actual church of the earthly kingdom. For Luther, the "invisible church" was the communion of saints (communio sanctorum). By communio, Luther meant a congregation or assembly (Gemeinde, Sammlung) of parties who were committed to the mutual sharing (communicare) of all things and experiences in this life, not least Christ himself. ${ }^{64}$ By sanctorum, Luther meant primarily all those sinners who had accepted Christ in faith and had so become saints. To be a saint was to be in community with other living persons who had accepted Christ in faith. It was also to be in communion with Christ and with all Christian believers who had died and had come into more perfect communion with Christ. ${ }^{65}$ The communion of saints thus began imperfectly in this life and continued perfectly in the life to come. The true church of the heavenly kingdom began temporally in this world of space and time, and continued eternally in the new world beyond space and time.

62. $10 / 3$ LUTHER, supra note 19 , at 108 .

63. For further discussion of the three natural orders of the earthly kingdom, see supra notes $41-42$ and accompanying text.

64. See 7 Luther, supra note 19 , at $219 ; 10 / 2 i d$. at $89 ; 28 i d$. at 149; PAUL Althaus, The Theology of Martin Luther 294322 (Robert C. Schultz trans., 1966).

65. See 35 LuTHER's Works, supra note 19 , at 50-51. 
The invisible church was a community of faith, hope and love, Luther argued. ${ }^{66}$ It featured a pure spiritual fellowship, a perennial ethic of mutual sharing and caring, each party ministering to the other in accordance with his or her special gifts. ${ }^{67}$ It was "the most divine, the most heavenly, the noblest fraternity, ... the community of holiness in which we are all brothers and sisters, so closely united that a closer relationship could not be conceived. Herein we have one baptism, one Christ, one sacrament, one food, one Gospel, one faith, one spirit, one spiritual body, with each person being a member of the other." 68

While this spiritual church remained an aspirational ideal for the world, it could only be seen "through a glass darkly," and only then by the keenest eyes of faith. In the earthly kingdom, Luther wrote, "the church is absconded, the saints are hidden."69 "Just as that rock [Jesus Christ], sinless, invisible and spiritual, is perceptible by faith alone so perforce the church is sinless, invisible and spiritual, perceptible by faith alone." ${ }^{70}$

The actual church of the earthly kingdom is only a shadow of this shining ideal, Luther argued, but dependent upon this ideal church like a shadow is dependent upon light for its being and form. The earthly church is comprised of both saints and sinners. Some are true believers, some are just imposters. Sometimes the true believers behave as saints, other times they behave as sinners. Thus God has established a visible church as one of the orders of the earthly kingdom. God has called this church to dispense his unique "gifts" to the earthly kingdom-the preaching of the Word, the administration of the sacraments, the discipline of the keys. All Christians, as members of the priesthood of all believers, have a general responsibility to help dispense these gifts. But from within the universal priesthood of believers, God also calls some to be the "priests" of the church-pastors, teachers, sextons and other church officers. These "priests" of the earthly church enjoy no special status in the earthly kingdom. Like the parent and like the prince, they simply have a distinctive office, neither more nor less important to God than other offices in the earthly kingdom. It was the responsibility of these priests, in tandem with the other earthly officers and orders, to see that the earthly church remained true to its office and faithful to its calling. ${ }^{71}$

\section{E. Theory of Knowledge}

Luther's two-kingdoms theory also drew to itself an epistemology, a theory of two sources and forms of knowledge. In his early years, Luther

66. See 6 LUTHER, supra note 19 , at 131.

67. See $10 / 3$ id. at $407 f f . ; 17 / 2$ id. at 255.

68. $2 \mathrm{id}$. at 756 .

69. $18 \mathrm{id}$. at 652 .

70. 7 id. at 710 .

71. See 40 Luther's Works, supra note 19 , at $325-47 ; 41 \mathrm{id}$. at $154 ; 38 \mathrm{id}$. at $188-214$. 
often described this in his favorite language of law and Gospel. The knowledge of the law brought death, the knowledge of the Gospel brought life. The truth revealed by the law is that we all are sinners. The truth revealed by the Gospel is that we all can be saints. To move from sinner to saint, from death to life, from the earthly kingdom to the heavenly kingdom required earnest cultivation and application of the knowledge of Christ taught in the Gospel. ${ }^{72}$

In his later years, Luther also came to describe this epistemological distinction in terms of faith versus reason, of revealed knowledge versus hidden knowledge. In the heavenly kingdom, Luther argued, God reveals himself directly through the Bible and through the Christian conscience. His Word and will are utterly clear to all those who have true faith. In the earthly kingdom, however, God is hidden, shrouded by the sin that has fallen over this kingdom. He is the "absconded God" (deus absconditus), whose truth and knowledge are revealed and known only through "masks" (larvae).

One such set of "masks," Luther argued, is a person's natural reason, which God has created with an inborn inclination to do good and to seek God. ${ }^{73}$ Cultivation of one's natural reason is essential to surviving in the earthly kingdom and to preparing oneself for the heavenly kingdom. "The light of reason is everywhere kindled by the divine light," Luther declared. "The light of reason ... is a part and beginning of the true light provided it recognizes and honors him by whom it is kindled ... . For wherever reason goes, there the will follows. Wherever the will goes, there love and desire follow."74 But the devil, too, is hidden in human reason and will, and distorts the natural knowledge and truth that God has implanted. A person, therefore, must not think that by willing to do good or by reasoning to find God, he or she will be able to move from the earthly kingdom to the heavenly kingdom, to attain salvation. ${ }^{75}$ Faith alone (sola fidei) brings salvation. Human reason and human will are always bound by sin-a point Luther pressed with great alacrity in his debate with Erasmus over the "bondage of the will." 76 "[R]eason when illuminated [by the Holy Spirit] helps faith by reflecting on something, but reason without faith isn't and can't be helpful."77

A second set of "masks" through which the hidden God can be partly seen in the earthly kingdom are the various offices of authority in the earthly orders of household, church and state. These offices not only rule the earthly kingdom on God's behalf, as we saw. But these authorities also

72. See Martin Luther, Commentary on Galatians (1525), in 26 LuTHer's Works, supra note 19, at 4-12 (containing summary of Luther's central thesis).

73. Cf. 1 id. at $66-67$.

74. 52 id. at 57,79 .

75. See 7 Luther, supra note 19, at 73; see also 39 id. at $374 ; 40$ id. at $42,66$.

76. See 33 LuTHER's Works, supra note 19, at 248-57.

77. 1 TISCHREDEN, supra note 23 , at No. 71 ; see 54 LUTHER's WORKs, supra note 19 , at 71 . 
communicate God's truth and knowledge, God's word and will, so far as they are able. ${ }^{78}$ " $[\mathrm{T}]$ he magistrate, the emperor, the king, the prince, the counsul, the teacher, the preacher, the pupil, the [parent] . .- -all these are masks [of God]," Luther argued. ${ }^{79}$ God wants us to "respect and acknowledge" them as his creatures and his teachers. ${ }^{80}$ These authorities are competent to teach much that is needed for life in the earthly kingdom, and a rational person would do well to heed their instruction. "But when the issue is one involving religion, conscience, the fear of God, faith, and the worship of God, then we must not fear or trust any [such earthly order] or look to it for consolation and rescue, either physical or spiritual."81 This would "offend [God]," and be a "denial of [his] truth." 82

A third set of "masks" by which the hidden God is partly revealed is the conscientious work of Christian believers in the earthly kingdom. It is the duty of Christians of all sorts "to work the work of God in the world," Luther argued. ${ }^{83}$ As citizens of the earthly kingdom, Christians were not to withdraw ascetically from the "things of the world," abstaining from its activities and institutions as certain Anabaptists of the day taught. ${ }^{84}$ Rather, Christians were to participate actively in these earthly institutions and activities, to confirm their natural origin and function, and to use human will and reason, however defective, to do as much good and to attain as much understanding as possible. "God himself ordained and established this earthly realm and its distinctions," Luther wrote. "[W]e must remain and work in them so long as we are on earth." 85

\section{F. Theory of Justice}

Finally, the two-kingdoms theory drew to itself a soteriology, a theory of two forms of justice or righteousness (justitia, Gerechtigkeit) and two corresponding uses of the law (duplex usus legis). We have already seen the heart of Luther's doctrine of justification by faith alone: sinners become saints, earthly citizens become heavenly citizens only through faith in Christ. No human works, however seemingly meritorious, will earn a person salvation. Luther's discussion of two forms of righteousness and two uses of law presented another dimension of this cardinal teaching, but now with an eye to explaining how and why good works might still be useful.

Earthly righteousness, Luther taught, "the righteousness of law or of works," is a natural righteousness whose norms, though ordained by God at creation, are perceived and carried out by the reason and will of sin-

78. See 26 Luther's Works, supra note 19 , at $94-96 ; 14$ id. at $114 ; 24$ id. at 67.

79. 26 id. at 95.

80. Id.

81. Id. at 96.

82. 26 id. at $95-96$.

83. See $31 / 1$ LutHer, supra note 19 , at $437 ; 40 / 3 \mathrm{id}$. at $271 \mathrm{ff}$.

84. $21 \mathrm{id}$. at $342 \mathrm{ff}$.

85. $32 \mathrm{id}$. at 390 . 
ners. Luther variously called this "active," "proper," "political" or "civil" righteousness. While this form of righteousness has no effect on one's citizenship in the heavenly kingdom, it does help to improve one's citizenship in the earthly kingdom. Earthly life for oneself and for all others is more livable and tolerable if a person does good, rather than evil. Heavenly righteousness, by contrast, "the righteousness of the Gospel or of faith," is a spiritual righteousness in which God alone acts. By grace, God inspires faith in a person's heart, and then by grace God responds to his faith, delivering him from sin and forgiving him. Luther, thus variously called this a form of "passive," "alien" or "foreign" righteousness. ${ }^{86}$ Luther summarized:

We set forth two worlds, ... one of them heavenly and the other earthly. Into these we place these two kinds of righteousness, which are distinct and separated from each other. The righteousness of the law is earthly and deals with earthly things; by it we perform good works. But as the earth does not bring forth fruit unless it first has been watered and made fruitful from above ... so also by the righteousness of the law we do nothing even when we do much; we do not fulfill the law, even when we fulfill it. Without any merit or work of our own, we must first be justified by Christian righteousness, which has nothing to do with the righteousness of the law or with earthly and active righteousness. But this righteousness is heavenly and passive. We do not have it of ourselves; we receive it from heaven. We do not perform it; we accept it by faith, through which we ascend beyond all laws and works. ${ }^{87}$

The corrollary to this doctrine of the two forms of righteousness is the doctrine of the two uses of the law. Once it is granted that salvation does not depend upon the works of the law, the question arises: Why does God continue to maintain the law of God and the law of the magistrate? What are, from God's point of view, its "uses" in the life of the earthly kingdom? Luther set forth two uses of the law, and touched on a third.

One use of the law, Luther argued, is to restrain people from sinful conduct by threat of punishment. ${ }^{88}$ Luther called this the "civil" or "political" use of the law. God wants even the worst of sinners to observe the law, Luther argued-to honor their parents, to avoid killing and stealing, to respect marriage vows, to testify truthfully and the like-so that "some

86. See $1 \mathrm{id}$. at 293ff.; see also 5 LutHeR's Works, supra note 19, at $213 \mathrm{ff}$.; 12 id. at $328 \mathrm{ff}$;; $31 \mathrm{id}$. at $297-306$.

87. 26 LUTHER's WORKs, supra note 19 , at 8.

88. See 10 LUTHER, supra note 19 , at $454 \mathrm{ff}$. Luther generally spoke of the "civil use" as the "first use of the law," and the "theological use" as the "second use of the law," though the latter was the more important to him. See id.; 40 id. at $486 \mathrm{ff}$;; Frank S. Alexander, Validity and Function of Law: The Reformation Doctrine of Usus Legis, 31 Mercer L. Rev. 509, 514-16 (1980). 
measure of earthly order, concourse and concord may be preserved." 89 Sinners, not naturally inclined to observe the law, may be induced to do so by fear of punishment-divine punishment as well as human punishment. "Stern hard civil rule is necessary in the world," Luther wrote, "lest the world be destroyed, peace vanish, and commerce and common interest be destroyed." 90 He emphasized that to maintain order it is important that there be precise legal rules, not only to deter lawbreakers but also to restrain magistrates from their natural inclination to wield their powers arbitrarily. ${ }^{91}$ This first use of the law applied both to the law of God and to the law of the magistrate. It induced in earthly citizens a "civil" or "political righteousness," a justice of law.

A second use of the law is to make people conscious of their duty to give themselves completely to God while, at the same time, making them aware of their utter inability to fulfill that duty without divine help. Luther called this the "theological use" of the law. The law in this sense serves as a mirror in which a sinner can reflect upon his depravity and see behind him the beckoning hand of a gracious God ready to forgive him and welcome him into the heavenly kingdom. Through the law, the sinful person is induced to acknowledge his sin and to seek God's gracious forgiveness. ${ }^{92}$ Here Luther relied on St. Paul's explanation of the significance of the law-to make persons conscious of their inherent sinfulness and to bring them to repentance. ${ }^{93}$ Luther sometimes put this in harsh terms: "The true office and the chief and proper use of the law is to reveal to man his sin, blindness, misery, wickedness, ignorance, hate, contempt of God, death, hell, judgment, and the well-deserved wrath of God .... When the law is being used correctly, it does nothing but reveal sin, work wrath, accuse, terrify, and reduce minds to the point of despair."94 From out of the depths of this despair, the sinner will cry to God for forgiveness and salvation. This second use of the law applied primarily to the law of God, though the laws of a true Christian magistrate could have the same effect. It induced in persons a "passive righteousness," a justice of faith, a recognition that one is entirely helpless in his own pursuit of heaven, and need only have faith in God's grace to be saved.

Luther also touched lightly on a third use of the law. This use, grounded in St. Paul's discussion of the law as "our teacher to bring us unto Christ,"95 became known in the Protestant world as the "educational" or "pedagogical" use of the law. ${ }^{96}$ Law, in this sense, serves to teach the

89. 10 LuTHER, supra note 19 , at $454 ; 11$ id. at 251.

90. $15 \mathrm{id}$. at 302.

91. See 3 Tischreden, supra note 23 , at No. 3911.

92. See 40 LuTHER, supra note 19 , at 481-86.

93. See 16 Luther, supra note 19 , at 363-93.

94. $40 \mathrm{id}$. at 481.

95. Galatians 3:24.

96. Philip Melanchthon was the first to expound systematically all three uses of the law in his Loci Communes Rerum Theologicorum (1535), reprinted in 21 
faithful, those who have already been justified by faith, the good works that please God. Luther recognized this concept without explicitly expounding a doctrine of the third use of the law. He recognized that those who are justified by faith remain sinful and in need of God's constant instruction through the law. He recognized that sermons, commentaries and catechism lessons on the many Old Testament passages on law are directed, in no small part, to teaching the faithful the meaning of God's law. ${ }^{97}$ He wrote cryptically early in his career of the "three-fold use of the law."98 Later, in Table Talk, he distinguished among "written law," "oral law" and "spiritual law" and then wrote that the spiritual law "touches the heart and moves it, so that a man not only ceases to persecute, but . . . desires to be better." 99 It is clear that, for Luther, law could serve not only as a harness against sin and an inducement to faith, but also as a teacher of Christian virtue.

But Luther never systematically expounded the third use of the law like his coworker Philip Melanchthon and many Protestant theologians and jurists did after 1535. Part of his resistance was exegetical: St. Paul's Galatians passage, after all, speaks of the law as "our teacher . . . until Christ" (pädagogus noster fuit in Christum).${ }^{100}$ Those who are already justified, by definition, have Christ, thus rendering the teacher's role fulfilled. Luther thus treated the teaching function of the law as part of its civil use.

Corpus Reformatorum 405-6 (G. Bretschneider ed., 1864). John Calvin also spoke of three uses of the law in John Calvin, Institutio Religionis Christianae (1536), reprinted in 29 CoRpus Reformatorum, supra, at 49-51. On other early expositions of three uses of the law, see Gerhard Ebeling, Word and Faith 62-78 (J. Leitsch trans., 1963); John Witte, Jr. \& Thomas C. Arthur, The Three Uses of the Law: A Protestant Source of the Purposes of Criminal Punishment?, 10 J.L. \& Religion 433, 433-448 (1994).

97. In his LARGE CA'TECHISM, which he described as "a set of instructions for the daily lives of Christian believers," Luther devoted more than fifty pages to exegesis of the Decalogue, concluding that "outside of the Ten Commandments, no work can be good or pleasing to God, however great or precious it may appear in the eyes of the world." Martin Luther, LARGe Catechism (1529), reprinted in Triglot Concordia: The Symbolic Books of the Evangelical lutheran Church, German-Latin-English 670/1 (F. Bente \& W. Dau trans., 1921) [hereinafter Luther, Large Catechism]. He included a similar exegesis in his Treatise ON GOOD WORKs (1520), reprinted in 6 LUTHER, supra note 19, at 196ff., and his Disputations Against the Antinomians (1539), reprinted in 47 Luther's Works, supra note 19 , at $107-14$.

98. In his Commentaky on Galatians (1522), Luther spoke of "three-fold use of the law" (drey uysse am brauch des gesetz), though in this tract as well as his ComMENTARY ON GAIATIANS (1531), he focused only on the civil and theological uses of the law. 10/1 LuTHER, supra note 19, at 449, 457. Martin Bucer, in his 1525 Latin translation of Luther's sermon, rendered Luther's German phrase as triplex usus legis, a Latin phrase that other reformers adopted. 10/1 id. at 457 n.2.

99. Martin luther, The Table Talk or Familiar Discourses of Martin LuTHER 135-36 (W. Hazlitt trans., 1848); see also 38 LUTHER, supra note 19, at 310.

100. Galatians 3:24 (emphasis added). 
The law was like a stern schoolteacher that kept unruly pupils in line until they had matured to self-restraint. ${ }^{101}$

Part of Luther's resistance was jurisdictional: law was the province of the earthly kingdom, while Gospel was the province of the heavenly kingdom. To acknowledge that Christians, members of the heavenly kingdom, still needed law to teach them was tacitly to admit that law might have a role in the heavenly kingdom, and the Gospel alone might not teach enough. This Luther could never allow. It was one thing to bring the Gospel down into the earthly kingdom. This Luther condoned happily. It was quite another thing to elevate the law to the heavenly kingdom. This could not be.

Part of Luther's resistance was also circumstantial: Unlike many later Protestant theologians, Luther did not develop a detailed doctrine of sanctification-a notion that a believer, upon justification by faith, might become holier, more sanctified, through subsequent good works defined by the law. ${ }^{102}$ A strong theological doctrine of the "third use of the law" went hand-in-hand with a strong doctrine of sanctification. Without the latter, Luther saw no need to develop the former, although he endorsed without qualification those Protestant confessions and treatises in which both these doctrines were set forth. ${ }^{103}$

\section{Implications for Theories of Society, Politics and Law}

This was the essence of Luther's mature two-kingdoms theory: God has ordained two kingdoms or realms in which humanity is destined to live, the earthly kingdom and the heavenly kingdom. The earthly kingdom is the realm of creation, of natural and civic life, where a person operates primarily by reason and law. The heavenly kingdom is the realm of redemption, of spiritual and eternal life, where a person operates primarily by faith and love. These two kingdoms embrace parallel forms of righteousness and justice, government and order, truth and knowledge. They interact and depend upon each other in a variety of ways. But these two kingdoms ultimately remain distinct. The earthly kingdom is distorted by sin, and governed by the law. The heavenly kingdom is renewed by grace and guided by the Gospel. A Christian is a citizen of both kingdoms at once and invariably comes under the distinctive government of each. As a heavenly citizen, the Christian remains free in his or her conscience, called to live fully by the light of the Word of God. But as an earthly citizen, the Christian is bound by law, and called to obey the natu-

101. See 26 Luther's Works, supra note 19, at 345-47; 27 id. at 278-79. "[T]he law is our custodian to Christ . . . after being driven and trained by the law we. . . [are] ready to seek and sigh for Christ, for faith, and for the inheritance." Id. at 279 .

102. See 25 Luther's Works, supra note 19 , at 371-78; 26 id. at 327-58.

103. See Wilfred Joest, Gesetz und Freiheit: Das Problem des tertius usus legis bei Luther und die neUtestamentliche Parainese (1968). 
ral orders and offices of household, state and church that God has ordained and maintained for the governance of this earthly kingdom.

This elegant dialectical theology provided the framework for several fundamental reforms of traditional theories of society, politics and law.

\section{A. Social Implications}

First, Luther's two-kingdoms theory was a rejection of traditional hiearchical theories of being, authority and society. For centuries, the Christian West had taught that God's creation is fundamentally hierarchical in structure-a vast chain of being emanating from God and extending down through the various kingdoms of humans, animals, plants and physical things. In this great chain of being, each creature found its place and its purpose, and the whole creation found its natural order. ${ }^{104}$ And in this chain of being, human society found its natural order and hierarchy. It was thus simply the nature of things that some persons and institutions were higher on this chain of being, some lower. It was the nature of things that some were closer and had more access to God, and some were further away and in need of greater mediation in their relationship with God. The hierarchical structure was one basis for traditional arguments of the superiority of the pope to the emperor, of the clergy to the laity, of the canon law to the civil law and of the church to the state. It was also one basis for the hierarchical doctrine of purgatory and paradise depicted so graphically in Dante's Divine Comedy-that vast hierarchy of purgation and sanctification that a confessed sinner slowly ascended in the afterlife in pursuit of recommunion with God.

Luther's two-kingdoms theory turned this traditional ontology onto its side. By separating the two kingdoms, Luther highlighted the radical separation between the Creator and the creation, and between God and humanity. For Luther, the fall into sin destroyed the original continuity and communion between the Creator and the creation, the tie between the heavenly kingdom and the earthly kingdom. There was no series of emanations of being from God to humanity. There was no stairway of merit from humanity to God. There was no purgatory. There was no heavenly hierarchy. God is present in the heavenly kingdom, and is revealed in the earthly kingdom primarily through "masks." Persons are born into the earthly kingdom, and have access to the heavenly kingdom only through faith.

104. See Arthur Lovejoy, The Chain of Being: A Study of the History of AN IDEA 59-66 (1936); see generally JACOB's LADdER AND THE TREe OF LIFE: CoNCEPTS of Hierarchy and the Great Chain of Being (Paul G. Kuntz \& Marion L. Kuntz eds., 1987). On the legal and ecclesiological implications of this ontology, see Brian Tierney, Religion, Law, and the Growth of Constitutional Thought: 1150-1650 8 (1982); Brian Tierney, Foundations of Conciliar Theory: The Contributions of the Medieval Canonists from Gratian to the Great Schism 96-98 (enlarged new ed. 1998). 
Luther did not deny the traditional view that the earthly kingdom retains its natural order, despite the fall into sin. There remained, in effect, a chain of being, an order of creation that gave each creature, especially each human creature and each natural institution, its proper place and purpose in this life. But, for Luther, this chain of being was horizontal, not hierarchical. Before God, all persons and all institutions in the earthly kingdom were by nature equal. Luther's earthly kingdom was a flat regime, a horizontal realm of being, with no person and no institution obstructed or mediated by any other in access to and accountability before God.

Second, and related, Luther's two-kingdoms theory turned the traditional hierarchical theory of human society onto its side. For many centuries, the church had taught that the clergy were superior to the laity. The clergy were, to adapt Luther's language, special officers of the higher heavenly realm of grace, while the laity were simply members of the lower earthly realm of nature. As members of the higher heavenly realm, the clergy had readier access to God and God's mysteries. They thus mediated the channel of grace between the laity and God-dispensing God's grace through the sacraments and preaching, and interceding for God's grace by hearing confessions, receiving charity and offering prayers on behalf of the laity. In this sense, the lowliest cleric was superior to the noblest emperor. All the clergy, from the lowliest parson to the greatest pope, were exempt from earthly laws, taxes and other duties and foreclosed from earthly pursuits such as marriage and family life.

Luther rejected this traditional social theory. Clergy and laity were fundamentally equal before God and before all others, he argued. Luther's doctrine of the priesthood of all believers at once "laicized" the clergy and "clericized" the laity. It treated the traditional "clerical" office of preaching and teaching as just another vocation, alongside many others, that a conscientious Christian could properly and freely pursue. He treated all traditional "lay" offices as forms of divine calling and priestly vocation, each providing unique opportunities for service to one's peers. Preachers and teachers of the visible church must carry their share of civic duties and pay their share of civil taxes just like everyone else. And they may and should participate in earthly activities such as marriage and family life just like everyone else.

Luther expanded on this natural egalitarianism with his robust understanding of the Christian "calling" (Beruf) or "vocation" (vocatio). Luther believed that every good, decent and useful occupation in which a Christian conscientiously engages should be treated as a Christian vocation. Each vocation was an equally virtuous and effective calling of God, though none was a pathway to salvation. ${ }^{105}$ Both the carpenter and the prince, the mineworker and the judge, the housewife and the banker should accept their Christian responsibility to perform their tasks conscientiously

105. See 46 LuTHER's Works, supra note 19 , at 93-137. 
and, so far as possible, in the service of God and others. Public officials, in particular, Luther argued, have a special calling to serve the community that might require them to adopt a Christian social ethic that differs from a Christian personal ethic. A Christian's duty in his direct relationship with God "as a private person, a person for himself alone," is to love his enemy and to suffer injustice and abuse from his neighbor without resistance and without revenge. As a public person, serving in such offices as the military or the judiciary, however, a Christian might well be required to resist his neighbor and to avenge injustice and abuse, even to the point of violence and bloodshed. ${ }^{106}$

Luther did not press his natural egalitarianism to communitarian extremes. He saw no incompatability between insisting on the equal status of all persons and vocations before God, and accepting the ample disparities in wealth, power, privilege and respectability among persons and positions in daily life. Some are more blessed, some less so. Some work harder, some play more. Some enjoy goods, some spurn them. Some start with noble inheritances, some start with nothing. Some vocations require more pageantry and property than others. None of these empirical disparities, however, changes the normative reality of human equality before God.

\section{B. Political Implications}

Luther's two-kingdoms theory also turned the traditional hierarchical theory of spiritual and temporal authority onto its side. For centuries, the Church had taught that the pope is the vicar of Christ, in whom Christ has vested the plentitude of his power. This power was symbolized in the "two swords" discussed in the Bible-the spiritual and the temporal swords. ${ }^{107}$ Christ had handed these two swords to the highest being in the human world-the pope, the vicar of Christ. The pope and his clerical delegates wielded the spiritual sword, in part by establishing canon law rules for the governance of all of Christendom. The pope, however, was too holy to wield the temporal sword. He thus delegated this sword to those authorities below the spiritual realm-emperors, kings, dukes and their civil retinues. These civil magistrates were to promulgate and enforce civil laws in a manner consistent with canon law and other church teachings. Under this two swords theory, civil law was by its nature inferior to canon law. Civil jurisdiction was subordinate to ecclesiastical jurisdiction. Political authority was subordinate to clerical authority. ${ }^{108}$

106. See 21 id. at $108-15 ; 46 i d$. at $93-99$.

107. See Luke 22:38.

108. On medieval formulations, see Lester L. Field, Liberty, Dominion, AND the Two Swords: On the Origins of Western Political. Theology (1998); Otto von Gierke, Political Theories of the Middle Age 7-21 (F.W. Maitland trans., repr. ed. 1958); 2 Ewart Lewis, Medieval Political Ideas 506-38 (1954). See generally Brian Tierney, The Crisis of Church and State, 1050-1300 (1964). 
Medieval popes could rarely make good on these grand claims to universal, preemptory legal authority in Christendom. Indeed, the strongest expressions of the two-swords theory came with Pope Boniface VIII's bull Unam Sanctum (1302) and its progeny when the papacy was losing its power and clutching ever more firmly to a waning ideal. ${ }^{109}$ But the twoswords theory remained a staple of traditional political theory in Germany. And a good number of strong German bishops and ecclesiastical princes in Luther's day were still making good on its claims in their local polities.

Luther rejected this hierarchical view of government. For Luther, the earthly kingdom featured three natural forms and forums of government: the domestic, ecclesiastical and political, or in modern terms, the family, the church and the state. These three institutions stood equal before God, and were each called directly by God to discharge complementary tasks in the earthly kingdom. The family was called to rear and nurture children, to teach and to discipline them, to cultivate and exemplify love and charity within the home and the broader community. The church was called to preach the Word, to administer the sacraments, to discipline its wayward members. The state was called to protect peace, punish crime, promote the common good and to support the church, family and other institutions derived from them.

These three estates were equal, rather than hierarchical, in authority, status and responsibility. Only the state had legal authority-the authority of the sword to pass and enforce positive laws for the governance of the earthly kingdom. Contrary to the two-swords theory, Luther emphasized that the church was not a law-making authority. The church had no sword. It had no jurisdiction. It had no business involving itself in the day-to-day administration of law or in the vesting of magistrates in their offices. The church's ministry and mission lay elsewhere. To be sure, each local church needed internal rules of order and discipline to govern its members and officers, and external legal structures to protect its polity and property. But it was up to the local magistrate to pass and enforce these ecclesiastical laws, in consultation and cooperation with the local clergy and theologians. And to be sure, church officers and theologians had to be vigilant in preaching and teaching the law of God to magistrates and subjects alike, and in pronouncing prophetically against injustice, abuse and tyranny. But formal legal authority lay with the state, not with the church. ${ }^{110}$

Luther was more concerned with the function than with the form of the state. Luther had, at first, hoped that the emperor would endorse the Reformation and accordingly included in his early writings some lofty panegyrics on the imperial authorities of the Holy Roman Empire of his day

109. See Pope Boniface VIII Unam Sanctum (1302), reprinted in Church and State Through the Centuries 82-92 (Sidney Z. Ehler \& John B. Morrall eds., 1954).

110. See 45 Luther's Works, supra note 19, at $105 \mathrm{ff}$;; 36 id. at $106 \mathrm{ff}$. 
and of the Christian Roman Empire of a millenium before. When the emperor failed him, Luther turned at various times to the nobility, the peasantry, the city councils and the princes, and wrote favorably about each of them (and sometimes unfavorably when they failed him). Such writings must be read in their immediate political context, however, and should not be used to paint Luther as a theorist of political absolutism, elitist oligarchy or constitutional democracy. Luther had no firm theory of the forms of political office. He did not sort out systematically the relative virtues and vices of monarchy, aristocracy or democracy. He spent very little time on the thorny constitutional questions of the nature and purpose of executive, legislative and judicial powers, let alone finer questions of checks and balances, judicial review and other such questions that had begun to occupy other sixteenth-century Protestant and humanist writers. These questions were not Luther's primary concern.

Luther was more concerned with the general status and function of the political office-both before God and within the community. On the one hand, Luther believed, the magistrate was God's vice-regent in the earthly kingdom, called to elaborate and enforce God's Word and will, to reflect God's justice and judgment on earthly citizens. The magistracy was, in this sense, a "divine office," a "holy estate," a "Godly calling," within the earthly kingdom. Indeed, the magistrate was a "god" on earth, as Psalm 82:6 put it, to be obeyed as if God himself. ${ }^{111}$ "Law and earthly government are a great gift of God to mankind," Luther wrote with ample flourish. "Earthly authority is an image, shadow, and figure of the dominion of Christ." Indeed, "a pious jurist" who served faithfully in the Christian magistrate's retinue is "a prophet, priest, angel, and savior . . . in the earthly kingdom."112

The magistrate and his retinue not only represented God's authority and majesty, however. They also exercised God's judgment and wrath against human sin. "[P] rinces and magistrates are the bows and arrows of God," Luther wrote, equipped to hunt down God's enemies in the earthly kingdom. ${ }^{113}$ The hand of the Christian magistrate, judge or soldier "that wields the sword and slays is not man's hand, but God's; and it is not man, but God, who hangs, tortures, beheads, slays and fights. All these are God's works and judgments." 114

On the other hand, Luther believed, the magistrate was the "father of the community" (Landesvater, paterpoliticus). The magistrate was to care for his political subjects as if they were his children, and his political subjects

111. See 2 id. at $139-42 ; 13 i d$. at $44 ; 44 i d$. at $92-95 ; 45$ id. at $85 f f . ; 46$ id. at $237-$ 40.

112. $30 / 2$ LUTHER, supra note 19 , at 554 .

113. 17 LUTHER's WoRKs, supra note 19, at 171.

114. 19 LuTHER, supra note 19, at 626; see also 6 id. at $267 ; 45$ LuTHER's Works, supra note 19 , at $113 ; 46 i d$. at 9-100. 
were to "honor" him as if he were their parent. ${ }^{115}$ This was the essence of the ordo politicus or Obrigkeit, of the political authorities and their subjects that comprise "the state." Like a loving father, the magistrate was to keep the peace and to protect his subjects from threats or violations to their persons, properties and reputations. ${ }^{116} \mathrm{He}$ was to deter his subjects from abusing themselves through drunkenness, sumptuousness, prostitution, gambling and other vices. ${ }^{117} \mathrm{He}$ was to nurture and sustain his subjects through the community chest, the public almshouse, the state-run hospice. ${ }^{118} \mathrm{He}$ was to educate them through the public school, the public library, the public lectern. ${ }^{119}$ He was to see to their spiritual needs by supporting the ministry of the locally established church, and encouraging their attendance and participation through the laws of Sabbath observance, tithing and holy days. He was to see to their material needs by reforming inheritance and property laws to ensure more even distribution of the parents' property among all children. ${ }^{120}$ He was to set an example of virtue, piety, love and charity in his own home and private life for his faithful subjects to emulate and to respect. The Christian magistrate was to complement and support the God-given responsibilities of parents and family members for their children and dependents, without intruding on the parental office. He was to support the preaching and sacramental life of the local church without trespassing on the ecclesiastical office, let alone that of the invisible church of the heavenly kingdom. ${ }^{121}$

These twin metaphors of the Christian magistrate-as the lofty viceregent of God and as the loving father of the community-described the basics of Luther's and Lutheran political theory. For Luther, political authority was divine in origin, but earthly in operation. Political authority expressed God's harsh judgment against sin but also his tender mercy for sinners. It communicated the law of God but also the lore of the local community. It depended upon the church for prophetic direction, but it took over from the church all jurisdiction-governance of marriage, education, poor relief and other earthly subjects traditionally governed by the church's canon law. Either metaphor standing alone could be a recipe for abusive tyranny or officious paternalism. But both metaphors together provided Luther and his followers with the core ingredients of a robust Christian republicanism and budding Christian welfare state.

115. See 30/1 LUTHER, supra note 19, at 152ff.; 13 LUTHER's WORKs, supra note 19, at 58-61; $44 \mathrm{id}$. at 81-99; LUTHER, LARGe CATECHISM, supra note 97, at 626-27. 225-36.

116. See 13 Luther's Works, supra note 19 , at $44-51 ; 45$ id. at $88-103 ; 46$ id. at

117. See 44 id. at 95-97; id. at 212-17.

118. See generally Abby Phyl lis Knobler, Luther and the Legal Concept of the Poor in the Sixteenth-Century German Church Ordinances (unpublished Ph.D. Diss. UCLA 1991) (on file with author); CARTER Lindberg, Beyond Charity: Reformation Initiatives for the PoOr (1993).

119. See WirTe, supra note 9 , at 267-72.

120. See OzMENT, supra note 17 , at 71-72.

121. See 45 LuTHER's Works, supra note 19, at 83-84, 104-13; 36 id. at 106-17. 


\section{Legal Implications}

Luther's two-kingdoms theory effectively "flattened" the traditional hierarchical theories of being and order, of clergy and laity and of ecclesiastical and political authority. His earthly kingdom was a horizontal realm with each person, each order and each official called directly by God to discharge discrete offices and vocations. What kept this earthly kingdom and its activities intact, Luther believed, was the law of God, and its elaboration by earthly authorities and subjects.

Luther defined the law of God as the set of norms ordained by God in the creation, written by God on the hearts of all persons and rewritten by God on the pages of the Bible. Luther called the law of God variously the "law of nature," "natural law," "divine law," "Godly law," "the law of the heart," "the teachings of conscience," "the inner law," among othersterms and concepts that he did not clearly differentiate either from each other or from traditional formulations. ${ }^{122}$ His main point was that God's natural law set at creation continued to operate after the fall into sin, and that it provided the foundation for all positive law and public morality in the earthly kingdom.

The natural law defined the basic obligations that a person owed to God, neighbor and self. The clearest expression of these obligations, for Luther, was the Ten Commandments, which God inscribed on two tables and gave to Moses on Mt. Sinai. The First Table of the Decalogue set out basic obligations to honor the Creator God, to respect God's name, to observe the Sabbath and to avoid idolatry and blasphemy. ${ }^{123}$ The Second Table set out basic obligations to respect one's neighbor-to honor authorities, and not to kill, commit adultery, steal, bear false witness or covet. ${ }^{124}$ Luther believed the Decalogue to be a universal statement of the natural law binding not only on the Jews of the Old Testament but on everyone. "The Decalogue is not the law of Moses . . but the Decalogue of the whole world, inscribed and engraved in the minds of all men from the foundation of the world."125 "[W] hoever knows the Ten Commandments perfectly must know all the Scriptures, so that, in all affairs and cases, he can advise, help, comfort, judge, and decide both spiritual and

122. For the collection of quotations, see generally Hermann W. Beyer, Lu-

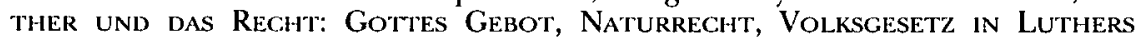
Deutung (1935). Among numerous studies, see Paul Althaus, The Ethics of Martin Luther 25-35 (Robert C. Schultz trans., 1972); Johannes Heckel, Lex Charitatis: Eine juristische Untersuchung ueber das Recht in Der Theologie Martin luthers 52 (1953); W.D.J. Cargill Thompson, The Political Thought of Martin Luther 87ff. (1984); John Tonkin, The Church and the Secular OrDer IN Reformation Thought 41-46 (1971); Joseph Binder, Zur Hermeneutik der Rechtslehre Martin Luthers, 51 Archiv für ReChts-und Sozialphilosophie 337-99 (1965); John T. McNeill, Natural Law in the Thought of Luther, 10 CHURCH Hist. 211, 215-25 (1941).

123. See 44 Luther's WORks, supra note 19, at 39-80.

124. See id. at 80-114; Luther, Large CateChISM, supra note 97, at 581-677.

125. 39/1 LUTHER, supra note 19 , at 478 . 
temporal matters, and is qualified to sit in judgment upon all doctrines, estates, spirits, laws, and whatever else is in the world."126 And again: "[A]lthough the Decalogue was given in a particular way and place and ceremony, . . all nations acknowledge that there are sins and iniquities." 127

Knowledge of this natural law comes not only through revealed Scripture, Luther argued, but also through natural reason-one of those "masks" by which the hidden God is partly revealed in the earthly kingdom. Luther built on St. Paul's notion that even the heathen have a "law written in their hearts, their conscience also bearing witness" to a natural knowledge of good and evil. ${ }^{128}$ Every rational person thus "feels" and "knows" the law of God, even if only obliquely. The basic teaching of the natural law "lives and shines in all human reason, and if people would only pay attention to it, what need would they have of books, teachers, or of law? For they carry with them in the recesses of the heart a living book which would tell them more than enough about what they ought to do, judge, accept, and reject."129

But sinful persons do not, of their own accord, "pay attention" to the natural law written on their hearts, and rewritten in the Bible. Thus God has called upon other persons and authorities in the earthly kingdom to elaborate its basic requirements. All Christians, as priests to their peers, must communicate the natural law of God by word and by deed. Parents must teach it to their children and dependents. Preachers must preach it to their congregants and catechumens. And magistrates must elaborate and enforce it through their positive laws and public policies.

The magistrate's elaboration and enforcement of the natural law is particularly important because only the magistrate holds formal legal authority in the earthly kingdom. "Natural law is a practical first principle in the realm of public morality," Luther wrote, "it forbids evil and commands good." "Positive law is a decision that takes local conditions into account," and "credibly" elaborates the general principles of the natural law into specific precepts to fit these local conditions. "The basis of natural law is God, who has created this light, but the basis of positive law is the earthly authority," the magistrate, who represents God in this earthly kingdom. ${ }^{130}$ The magistrate must promulgate and enforce these positive laws by combining faith, reason and tradition. He must pray to God earnestly for wisdom and instruction. He must maintain "an untrammelled reason" in judging the needs of his people and the advice of his counselors. ${ }^{131} \mathrm{He}$ must consider the wisdom of the legal tradition-particularly that of Ro-

126. Luther, Large Catechism, supra note 97 , at 573.

127. $39 / 1$ LuTHER, supra note 19 , at $540 ; 18 \mathrm{id}$. at $72 ; 30 \mathrm{id}$. at 192.

128. Romans 2:14-15.

129. $17 / 2$ LUTHER, supra note 19 , at 102 .

130. 3 TISCHREDEN, supra note 23 , at No. 3911 ; see 51 LUTHER, supra note 19 , at 211.

131. 45 LuTHER's Works, supra note 19 , at 120-26. 
man law, which Luther called a form of "heathen wisdom."132 "The polity and the economy" of the earthly kingdom, Luther wrote, "are subject to reason. Reason has first place. There [one finds] civil laws and civil justice."133

\section{Protestant Instincts About Law, Society and Human Nature}

A century ago, most Protestants viewed Martin Luther as the faithful David who felled the papal Goliath with the single stones of sacred Scripture. Most Catholics viewed Luther as the seven-headed demon who destroyed Western Christendom with his heretical ranting. For most Protestants, Luther was the great prophet of modern liberty who freed Western law and culture from the oppressive rule of the Catholic Church. For most Catholics, Luther was the grim priest of secularism, who cut Western law and culture from their essential religious roots. ${ }^{134}$

Today, such confessional caricatures of Luther and the Reformation are happily fading. Most Protestants have now begun to recognize that the Lutheran Reformation was part and product of a whole series of late medieval reform movements, and that Luther and his followers depended upon Catholic theology and canon law for many of their cardinal ideas and institutions. Most Catholics have now begun to recognize Luther as a loud but inspired prophet for an alternative Christian view of law and politics, a shrill but shrewd architect of a new biblical theology of human nature, social pluralism and religious liberty, a good deal of which the modern Catholic Church now embraces. ${ }^{135}$

That said, it must also be said that Luther's insights still give a distinctive orientation to many contemporary Protestants' instincts about law, society and human nature. Three clusters of legal ideas are worth pointing out.

First, Luther's doctrine of simul iustus et peccator renders many Protestants today instinctively skeptical about too optimistic a view of human nature, and too easy a conflation of human dignity and human sanctity. Such views take too little account of the radicality of human sin and the

132. 51 LuTHER, supra note 19 , at 242 ; see also 12 id. at $243 ; 14 i d$. at 591,714 ; $16 \mathrm{id}$. at 537; 30/2 id. at 557; $51 \mathrm{id}$. at 241; discussion in HECKEL, supra note 122, at $82 \mathrm{ff}$.

133. 40 LUTHER, supra note 19 , at 305.

134. On various images of Luther, see, for example, Seven-Headed Luther 3, 13 (Peter N. Brooks, ed. 1983); EDWARds, supra note 19, at 83; JACQUES MARITAIN, Three Reformers: Luther-Descartes-Rousseau 15 (1947); Robert Scribner, For the Sake of Simple Folk: Popular Propaganda for the German Reformation 14-36, 229-39 (1981); James Stayer, Martin Luther, German Saviour: German Evangelical Theological factions and the Interpretation of Luther, 1917-1933 (2000).

135. For sources and discussion, see John Witte, Jr., A Dickensian Era of Religious Rights: An Update on Religious Human Rights in Global Perspective, 42 WM. \& MaRY L. Rev. 707, 728-31 (2001); John Witte, Jr., The Goods and Goals of Marriage, 76 Notre Dame L. Rev. 1019, 1039-71 (2001). 
necessity of divine grace. They give too little credibility to the inherent human need for discipline and order, accountability and judgment. They give too little credence to the perennial interplay of the civil, theological and pedagogical uses of law, to the perpetual demand to balance deterrence, retribution and reformation in discharging authority within the home, church, state and other associations. They give too little insight into the necessity for safeguarding every office of authority from abuse and misuse. A theory of human dignity that fails to take into account the combined depravity and sanctity of the human person is theologically and politically deficient, if not dangerous.

This cardinal insight into the two-fold nature of humanity was hardly unique to Martin Luther, and is readily amenable to many other formulations. Luther's formula of simul iustus et peccator was a crisp Christian distillation of a universal insight about human nature that can be traced to the earliest Greek and Hebrew sources of the West. The gripping dramas of Homer, Hesiod and Pindar are nothing if not chronicles of the perennial dialectic of good and evil, virtue and vice, hero and villain in the ancient Greek world. The very first chapters of the Hebrew Bible paint pictures of these same two human natures with Yahweh's imprint on them. The more familiar picture is that of Adam and Eve who were created equally in the image of God, and vested with a natural right and duty to perpetuate life, to cultivate property, to dress and keep the creation. ${ }^{136}$ The less familiar picture is that of their first child Cain, who murdered his brother Abel and was called into judgment by God and condemned for his sin. Yet "God put a mark on Cain," 137 Genesis reads, both to protect him in his life, and to show that he remained a child of God despite the enormity of his $\sin .^{138}$ One message of this ancient Hebrew text is that we are not only the beloved children of Adam and Eve, who bear the image of God, with all the divine perquisites and privileges of Paradise. We are also the sinful siblings of Cain, who bear the mark of God, with its ominous assurance both that we shall be called into divine judgment for what we have done, and that there is forgiveness even for the gravest of sins we have committed.

Luther believed that it is only through faith and hope in Christ that a person can ultimately be assured of divine forgiveness and eternal salvation. He further believed that it was only through a life of biblical meditation, prayer, worship, charity and sacramental living that a person could hold his or her depravity in check and aspire to greater sanctity. I happen to believe that, too, as do many Christians today. But this is not to say that, in this life, Christians have the only insights into the two-fold nature of humanity, and the only effective means of balancing the realities of human depravity and the aspirations for human sanctity. Any religious

136. See Genesis 1:26-30; id. at 2:7, 15-23.

137. Id. at $4: 15$.

138. This is but one of the numerous interpretations of the story of Cain and Abel. For alternatives, see Ruth Mellinkoff, The Mark of CAin 23-80 (1981); Claus Westermann, Genesis 1-11: A Commentary 279-320 (repr. ed. 1990). 
tradition that takes seriously the Jekyll and Hyde in all of us has its own understanding of ultimate reconciliation of these two natures, and its own methods of balancing them in this life. And who are Christians to say how God will ultimately judge these?

Luther also believed that the ominous assurance of the judgment of God is ultimately a source of comfort, not of fear. The first sinners in the Bible-Adam, Eve and Cain-were given divine due process: they were confronted with the evidence, asked to defend themselves, given a chance to repent, spared the ultimate sanction of death and then assured of a second trial on the Day of Judgment, with appointed divine counsel. The only time that God deliberately withheld divine due process, Luther reminds us, was in the capital trial of His Son-and that was the only time it was and has been necessary. The political implications of this are very simple: if God gives due process in judging us, we should give due process in judging others. If God's tribunals feature at least basic rules of procedure, evidence, representation and advocacy, human tribunals should feature at least the same. The demand for due process is a deep human instinct, and it has driven Protestants over the centuries, along with many others before and with them, to be strident advocates for procedural rights.

Second, Luther's doctrine of the lordship and priesthood of all believers renders many Protestants instinctively jealous about liberty and equality-but on their own quite distinct theological terms. In the modern liberal tradition, liberty and equality are generally defended on grounds of popular sovereignty and inalienable rights. The American Declaration of Independence (1776) proclaimed it a "self-evident truth" "that all men are created equal [and] . . . are endowed with certain unalienable rights."139 The Universal Declaration of Human Rights (1948) proclaimed "[ $\mathrm{t}]$ hat all human beings are born free and equal in rights and dignity." 140 Protestants can resonate more with the norms of liberty and equality in these documents than with the theories of popular sovereignty and inalienable rights that generally undergird them.

The heart of the Protestant theory of liberty is that we are all lords on this earth. We are utterly free in the sanctuary of our conscience, entirely unencumbered in our relationship with God. We enjoy a sovereign immunity from any human structures and strictures, even those of the church, when they seek to impose upon this divine freedom. Such talk of "sovereign immunity" sounds something like modern liberal notions of "popular sovereignty." And such talk of "lordship" sounds something like the democratic right to "self-rule." Protestants have thus long found ready allies in liberals and others who advocate liberty of conscience and democratic freedoms on these grounds. But, when theologically pressed, many Protestants will defend liberty of conscience not because of their own popular

139. The Declaration of Independence para. 2 (U.S. 1776).

140. Basic Documents on Human Rights 22 (Ian Brownlie ed., 3d ed. 1992). 
sovereignty, but because of the absolute sovereignty of God, whose relationship with his children cannot be trespassed. Many Protestants will defend certain unalienable rights, like freedom of conscience, not in the interest of preserving their personal privacy, but in the interest of discharging their divine duties.

The heart of the Protestant theory of equality is that we are all priests before God. "You are a chosen race, a royal priesthood, a holy nation, God's own people."141 Among you, "[t]here is neither Jew nor Greek, there is neither bond nor free, there is neither male nor female; for you are all one in Christ Jesus." 142 These and many other biblical passages, which Luther highlighted and glossed repeatedly, have long inspired a reflexive egalitarian impulse in Protestants. All are equal before God. All are priests that must serve their neighbors. All have vocations that count. All have gifts to be included. This common calling of all to be priests transcends differences of culture, economy, gender and more.

Such teachings have led a few Protestant groups over the centuries to experiment with intensely communitarian states of nature where life is gracious, lovely and long. Most Protestant groups, however, view life in such states of nature as brutish, nasty and short, for sin invariably perverts them. Structures and strictures of law and authority are necessary and useful, many Protestants believe; but such structures need to be as open, egalitarian and democratic as possible. Hierarchy is a danger to be indulged only so far as necessary. To be sure, Protestants over the centuries have often defied these founding ideals and have earnestly partaken of all manner of elitism, chauvinism, racism, anti-Semitism, tyranny, patriarchy, slavery, apartheid and more. And they have sometimes engaged in outrageous hypocrisy and casuistry to defend such shameful pathos. But an instinct for egalitarianism-for embracing all persons equally, for treating all vocations respectfully, for arranging all associations horizontally, for leveling the life of the earthly kingdom so none is obstructed in access to God-is a Lutheran gene in the theological genetic code of Protestantism.

Third, and finally, Luther's notion that a person is at once free and bound by the law has powerful implications for our modern understanding of human rights. For Luther, the Christian is free in order to follow the commandments of the faith-or, in more familiar and general modern parlance, a person has rights in order to discharge duties. Freedoms and commandments, rights and duties belong together in Luther's formulation. To speak of one without the other is ultimately destructive. Rights without duties to guide them quickly become claims of self-indulgence. Duties without rights to exercise them quickly become sources of deep guilt.

141. 1 Peter 2:9 (RSV); of. Revelation 5:10; id. at 20:6.

142. Galatians 3:28 (RSV); cf. Colossians 3:10-11; Ephesians 2:14-15. 
Protestants have thus long translated the moral duties set out in the Decalogue into reciprocal rights. The First Table of the Decalogue prescribes duties of love that each person owes to God-to honor God and God's name, to observe the Sabbath day of rest and holy worship and to avoid false gods and false swearing. The Second Table prescribes duties of love that each person owes to neighbors-to honor one's parents and other authorities, not to kill, not to commit adultery, not to steal, not to bear false witness, not to covet. Church, state and family alike are responsible for the communication and enforcement of these cardinal moral duties. But it is also the responsibility of each person to ensure that he and his neighbors discharge these moral duties.

This is an important impetus for Protestants to translate duties into rights. Each person's duties toward God can be cast as the rights of religion: the right to honor God and God's name, the right to rest and worship on one's Sabbath and the right to be free from false gods and false oaths. Each person's duties towards a neighbor, in turn, can be cast as a neighbor's right to have that duty discharged. One person's duties not to kill, to commit adultery, to steal or to bear false witness thus give rise to another person's rights to life, property, fidelity and reputation. For a person to insist upon vindication of these latter rights is not necessarily to act out of self-love; it is also to act out of neighborly love. To claim one's own right is in part a charitable act to induce one's neighbor to discharge his or her divinely-ordained duty.

We began with Grant Gilmore's provocative summary of a typical view of law, which Luther did much to propound in his early writings. "The better the society the less law there will be," Gilmore wrote. "In Heaven there will be no law, and the lion will lie down with the lamb.... In Hell there will be nothing but law, and due process will be meticulously observed."143 A Protestant faithful to Luther's later and more enduring insights, however, might properly reach the exact opposite projection. In Heaven, there will be pure law, and thus the lamb will lie down with the lion. In Hell, there will be no law, and thus all will devour each other eternally. Heaven will exalt due process and each will always receive what's due. Hell will exalt pure caprice and no one will ever know what's coming.

143. Gilmore, supra note 1 , at 111. 